\title{
KEMAMPUAN MEMAHAMI \\ TEKS EKSPLANASI PESERTA DIDIK KELAS VIII SMP NEGERI 24 BANJARMASIN
}

\author{
Ramlah; Jumadi; Sainul Hermawan \\ Program Studi Pendidikan Bahasa dan Sastra Indonesia \\ FKIP Universitas Lambung Mangkurat \\ amlaharianil@gmail.com
}

\begin{abstract}
Abstrak
Pembelajaran Bahasa Indonesia ialah salah satu pelajaran yang wajib dilaksanakan di sekolah terutama di Indonesia. Pada kurikulum 2013 yang mengharuskan pembelajaran Bahasa Indonesia berbasis teks. Diantaranya ialah teks eksplanasi. Tujuan dari penelitian ini ialah untuk mendeskripsikan kemampuan memahami teks eksplanasi peserta didik kelas VIII SMP NEGERI 24 Banjarmasin. Adapun aspek yang akan diteliti meliputi (1) aspek kebahasaan teks eksplanasi, dan (2) memahami isi teks eksplanasi. Metode yang digunakan ialah metode deksriptif kuantitatif. Kemudian, hasil dari penelitian ini menunjukkan bahwa: 1) nilai yang diperoleh peserta didik dalam tes kemampuan memahami aspek kebahasaan teks eksplanasi adalah 77,69 dengan rincian 3,8\% tidak mampu, 3,8\% kurang mampu, 19,2\% сиkup mampu, 15,4\% mampu, dan 57,8\% sangat татри memahami aspek kebahasaan teks eksplanasi, 2) nilai yang diperoleh peserta didik untuk tes kemampuan memahami isi teks eksplanasi adalah 71,61 dengan rincian 3,8\% tidak mampu, 7.7\% kurang mampu, 23,1\% cukup mampu, 34,6\% mampu, dan $30.8 \%$ sangat mampu.
\end{abstract}

Kata kunci: kemampuan, memahami, teks eksplanasi

\section{Pendahuluan}

Sesuai dengan silabus mata pelajaran Bahasa Indonesia pada Kurikulum 2013, salah satu tema pembelajaran Bahasa Indonesia adalah teks eksplanasi yang terdapat pada Kompetensi Dasar (KD) 3.1.

Teks eksplanasi merupakan teks yang memuat tentang proses fenomena alam, maupun sosial, budaya yang memiliki hubungan sebab-akibat.

Rumusan masalah yang diperoleh yaitu:

1) Bagaimana kemampuan memahami aspek kebahasaan teks eksplanasi peserta didik kelas VIII SMP Negeri 24 Banjarmasin?

2) Bagaimana kemampuan memahami isi teks eksplanasi pesertadidik kelas VIII SMP Negeri 24 Banjarmasin?

Tujuan penelitian ini dilakukan, yaitu;

1) Mendeskripsikan kemampuan memahami aspek kebahasaan teks eksplanasi peserta didik kelas VIII SMP Negeri 24 Banjarmasin.

2) Mendeskripsikan kemampuan memahami isi teks eksplanasi peserta didik kelas VIII SMP Negeri 24 Banjrmasin. 


\section{Metode Penelitian}

\section{Jenis Penelitian}

Penelitian

menggunakan

pendekatan deskriptif kuantitatif.

Pendekatan kuantitatif dilakukan untuk penghitungan jumlah skor dan metode deskriftif digunakan untuk menjabarkan jumlah skor yang telah diperoleh peserta didik.

\section{Waktu dan Tempat Penelitian}

Penelitian dilakukan pada 09 Februari 2019 bertempat di SMP Negeri 24 Banjarmasin.

\section{Populasi dan Sampel}

Populasi penelitian ini berjumlah 260, meliputi seluruh peserta didik di kelas VIII terdiri dari VIII-A sampai VIII-H. Sampel diambil sebanyak 10\% dari jumlah populasi, yang dimana jumlah $10 \%$ dari 260 peserta didik diperoleh sebanyak 26 orang untuk mewakili populasi penelitian.

\section{Instrumen Penelitian}

Instrumen berupa tes pilihan ganda yang diberikan pada peserta didik dalam bentuk lembar kerja siswa. Soal yang diberikan berjumlah 50 (lima puluh) soal dalam bentuk multiple choice (pilihan ganda) yang terdiri dari
25 soal mengenai aspek kebahasaan teks eksplanasi dan 25 soal mengenai memahami isi atau makna dari teks eksplanasi.

\section{Teknik Pengumpulan Data}

Peneliti membagikan soal pilihan ganda sebanyak 50 (lima puluh) soal kepada peserta didik yang terdiri dari 25 (dua puluh lima) soal mengenai aspek kebahasaan teks eksplanasi dan 25 (dua puluh lima) soal mengenai memahami isi teks eksplanasi. Satu soal yang dijawab dengan benar bernilai 4 (empat) dan yang salah bernilai 0 (nol). Jadi skor maksimal yang diperoleh adalah 25 X $4=100$, skala nilai 0-100 untuk setiap kategori yang disajikan . Waktu untuk mengerjakan soal ialah 2 X 40 menit.

\section{Teknik Analisis Data}

$\begin{array}{rrr}\text { Penelitian } & \text { yang } & \text { dilakukan } \\ \text { menggunakan } & \text { teknik } & \text { kuantitatif }\end{array}$ deskriptif. Teknik ini digunakan untuk menganalisis hasil tes berupa tes pemahaman teks eksplanasi dan tes pemahaman isi tesk eksplanasi. skor yang diperoleh peserta didik akan dianalisis dengan cara statistik, deskriptif, meliputi kegiatan mengumpulkan data, mengolah data, 
dan menyajikan data dengan menggunakan tabel.

Penulis menggunakan data dari hasil butir soal yang telah dijawab oleh peserta didik untuk kemudian mengolah data mengenai Kemampuan Memahami Teks Eksplanasi. Tahap selanjutnya, menganalisis data yang dilakukan denga beberapa tahapan:

1). Membuat tabel skor mentah

2).Membuat tabel persentase dari skor mentah.

3).Menentukan nilai rerata peserta ddik, dengan rumus rerata berikut:

$$
\bar{x}=\frac{\sum x}{N}
$$

$\bar{x}=$ mean (nilai rerata)

$\sum x=$ Jumlah seluruh nilai

$\mathrm{N}=$ Jumlah sampel

(e-journal, Fadilah, 2019)

3) Membuat klasifikasi kemampuan memahami teks eksplanasi dengan menampilkan histogram (pie chart) dari hasil olahan data.

\section{Hasil Penelitian dan Pembahasan}

Data yang diolah adalah skor mentah hasil dari tes yang dilaksankan pada penelitian ini berupa kemampuan memahami teks eksplanasi. Penyajian dari hasil penelitian terdiri atas dua bagian, yakni:
1. Kemampuan Peserta Didik

Memahami Aspek Kebahasaan

Teks Eksplanasi.

Data yang dinilai kemudian dibuatkan tabel untuk menghitung frekuensi dan persentase dari data tersebut. Kemudian dilakukan perhitungan rerata nilai peserta didik. Hal ini bertujuan untuuk mengetahui kemampuan memahami aspek kebahasaan teks eksplanasi. Hasil perhitungan skor, lihat pada tabel di bawah ini.

Tabel 4.1

Daftar Skor Mentah Memahami Aspek Kebahasaan Teks Eksplanasi

\begin{tabular}{|l|l|l|l|}
\hline No & \multicolumn{1}{|c|}{ Nama } & $\begin{array}{c}\text { Soal } \\
\text { Benar }\end{array}$ & Skor \\
\hline 1 & Amelia P. & 20 & 80 \\
\hline 2 & Annisa S. & 24 & 96 \\
\hline 3 & Azhar R. & 13 & 52 \\
\hline 4 & Faza N. A. & 23 & 92 \\
\hline 5 & Gusti A. C. & 23 & 92 \\
\hline 6 & Julia H. & 20 & 80 \\
\hline 7 & M. Albin H. & 20 & 80 \\
\hline 8 & M. Aulia R. A & 22 & 88 \\
\hline 9 & M. Azmi F. & 25 & 100 \\
\hline 10 & M. Bisri & 16 & 64 \\
\hline 11 & M. Ilham & 11 & 44 \\
\hline 12 & M. Irsyad R. & 19 & 76 \\
\hline 13 & M. Luthfi F. & 17 & 68 \\
\hline 14 & M. Mas'ud S. & 15 & 60 \\
\hline 15 & M. Rafha N. & 19 & 76 \\
\hline 16 & M. Raihan & 23 & 92 \\
\hline & & & \\
\hline
\end{tabular}




\begin{tabular}{|l|l|l|l|}
\hline 17 & Melani S. & 24 & 96 \\
\hline 18 & Melly O. Z. & 19 & 76 \\
\hline 19 & Meylin P. D. & 17 & 68 \\
\hline 20 & $\begin{array}{l}\text { Najla } \\
\text { Salsabila }\end{array}$ & 16 & 64 \\
\hline 21 & Namira K. P. & 20 & 80 \\
\hline 22 & Nanda A. R. & 20 & 80 \\
\hline 23 & Nor Ain S. & 20 & 80 \\
\hline 24 & Ovy Febrya P. & 20 & 80 \\
\hline 25 & Rahmad A. R. & 20 & 80 \\
\hline 26 & Ridho A. & 19 & 76 \\
\hline & Jumlah & & $\mathbf{2 . 0 2 0}$ \\
\hline
\end{tabular}

Sesuai dengan tabel yang disajikan, bahwa nilai tertinggi ialah 100 (seratus) diraih oleh M. Azmi Firzada dan nilai terendah peserta didik adalah 44 (empat puluh empat) diraih oleh M. Ilham. Serta jumlah seluruh nilai peserta didik adalah 2.020.

Tabel 4.2

Daftar Frekuensi dan Persentase Skor Mentah Eksplanasi

\begin{tabular}{|c|c|c|c|}
\hline Nilai & Frekuensi & Persen & Jumlah \\
\hline 44 & 1 & $3,8 \%$ & 44 \\
\hline 52 & 1 & $3,8 \%$ & 52 \\
\hline 60 & 1 & $3,8 \%$ & 60 \\
\hline 64 & 2 & $7,8 \%$ & 128 \\
\hline 68 & 2 & $7,8 \%$ & 136 \\
\hline 76 & 4 & $15,4 \%$ & 304 \\
\hline 80 & 8 & $30,8 \%$ & 640 \\
\hline 88 & 1 & $3,8 \%$ & 88 \\
\hline 92 & 3 & $11,5 \%$ & 276 \\
\hline 96 & 2 & $7,7 \%$ & 192 \\
\hline 100 & 1 & $3,8 \%$ & 100 \\
\hline Total & $\mathbf{2 6}$ & $\mathbf{1 0 0 . 0}$ & $\mathbf{2 . 0 2 0}$ \\
\hline
\end{tabular}

Sebelumnya telah diketahui nilai tertinggi ialah 100 dan nilai terendah adalah 44. Kemudian, nilai 52 dan 60 masing-masing dicapai satu atau 3,8\% peserta didik. Nilai 64 dan 68 masingmasing dicapai oleh dua atau $7,8 \%$ peserta didik. Nilai 76 dicapai oleh empat atau $15,4 \%$ peserta didik. Nilai 88 dicapai oleh satu atau $3.8 \%$ peserta didik. Nilai 92 dicapai oleh tiga atau 11,5\%. nilai 96 dicapai oleh dua atau $7,7 \%$. Nilai terbanyak yang diperoleh adalah 80 berjumlah 8 atau $30,8 \%$ peserta didik.

Berdasarkan nilai pada Tabel 4.2 di atas, dapat dilihat rentangan nilai yang dicapai berada pada rentang 44-100 dan dari 26 sampel peserta didik yang memperoleh nilai di rentang 76-100 hanya ada 19 sampel peserta didik, sedangkan 7 (tujuh) sampel peserta didik lainnya berada pada rentang nilai 0-78.

Diketahui dari Tabel 4.1 jumlah nilai yang didapat peserta didik untuk memahami aspek kebahasaan teks eksplanasi sejumlah 2.020, dengan jumlah sampel sebanyak 26 orang, dapat diperoleh nilai rerata peserta didik kelas VIII SMP Negeri 24 Banjarmasin, yaitu:

$$
\begin{gathered}
\bar{x}=\frac{\sum x}{N} \\
\bar{x}=\frac{2.020}{26}
\end{gathered}
$$$$
=77,69
$$ 
Nilai rerata peserta didik memahami aspek kebahasaan teks eksplanasi adalah 77,69.

Tabel 4.3

Kemampuan Memahami Aspek Kebahasaan Teks Eksplanasi

\begin{tabular}{|l|r|r|r|}
\hline Rincian & \multicolumn{1}{|c|}{ F } & Persen & Akumulasi \\
\hline Tidak & 1 & $3,8 \%$ & 3.8 \\
Mampu & & & 7.7 \\
\hline $\begin{array}{l}\text { Kurang } \\
\text { Mampu }\end{array}$ & 1 & $3,8 \%$ & 26.9 \\
\hline $\begin{array}{c}\text { Cukup } \\
\text { Mampu }\end{array}$ & 5 & $19,2 \%$ & 42.3 \\
\hline Mampu & 4 & $15,4 \%$ & 100.0 \\
\hline $\begin{array}{c}\text { Sangat } \\
\text { Mampu }\end{array}$ & 15 & $57,8 \%$ & \\
\hline Total & $\mathbf{2 6}$ & $\mathbf{1 0 0 . 0}$ & \\
\hline
\end{tabular}

Tabel 4.3 dapat diketahui lima belas $(57,8 \%)$ peserta didik yang sangat татри memahami aspek kebahasaan teks eksplanasi, sedangkan frekuensi terendah terdapat satu $(3,8 \%)$ peserta didik yang tidak mampu memahami aspek kebahasaan teks eksplanasi. Terdapat satu $(3,8 \%)$ pesertadidik yang kurang mampu, 5 (19,2\%) yang cukup татри, dan empat $(15,4 \%)$ peserta didik mampu memhami aspek kebahasaan teks eksplanasi.

\section{Kemampuan Peserta Didik}

\section{Memahami Isi Teks Eksplanasi.}

Data yang diperoleh dari hasil penelitian, kemudian data diberi skor berdasarkan rubrik penilaian kemampuan memahami teks eksplanasi.

Sampel yang telah dinilai kemudian dibuat dalam bentuk tabel untuk menghitung frekuensi dan persentase dari data tersebut. Kemudian dilakukan perhitungan nilai rerata.. Hasil perhitungan skor dapat dilihat pada tabel berikut.

Tabel 4.4

Daftar Skor Mentah Memahami Isi Teks Eksplanasi

\begin{tabular}{|c|l|l|l|}
\hline No & \multicolumn{1}{|c|}{ Nama } & $\begin{array}{l}\text { Soal } \\
\text { Benar }\end{array}$ & Skor \\
\hline 1 & Amelia P. & 17 & 68 \\
\hline 2 & Annisa S. & 18 & 72 \\
\hline 3 & Azhar R. & 17 & 68 \\
\hline 4 & Faza N. A. & 16 & 62 \\
\hline 5 & Gusti A. C. & 20 & 80 \\
\hline 6 & Julia H. & 20 & 80 \\
\hline 7 & M. Albin H. & 18 & 72 \\
\hline 8 & M. Aulia R. A. & 21 & 84 \\
\hline 9 & M. Azmi F. & 20 & 80 \\
\hline 10 & M. Bisri & 17 & 68 \\
\hline 11 & M. Ilham & 18 & 72 \\
\hline 12 & M. Irsyad R. & 19 & 76 \\
\hline 13 & M. Luthfi F. & 21 & 84 \\
\hline 14 & M. Mas'ud S. & 19 & 76 \\
\hline 15 & M. Rafha N. & 20 & 80 \\
\hline 16 & M. Raihan & 13 & 52 \\
\hline 17 & Melani S. & 18 & 72 \\
\hline 18 & Melly O. Z. & 20 & 80 \\
\hline 19 & Meylin P. D & 12 & 48 \\
\hline 20 & Najla S. & 18 & 72 \\
\hline 21 & Namira K. P. & 20 & 80 \\
\hline 22 & Nanda A. R. & 18 & 72 \\
\hline 23 & Nor Ain S. & 18 & 72 \\
\hline 24 & Ovy Febrya P. & 17 & 68 \\
\hline
\end{tabular}




\begin{tabular}{|l|l|l|l|}
\hline 25 & Rahmad A. R. & 14 & 56 \\
\hline 26 & Ridho Ansari & 17 & 68 \\
\hline & Jumlah & & $\mathbf{1 . 8 6 2}$ \\
\hline
\end{tabular}

Sesuai pada Tabel 4.4, diketahui 84 adalah nilai tertinggi diraih oleh dua peserta didik atas nama M. Luthfi Fuadi dan M. Aulia Rahman Al-kausar dan skor terendah 48 yang diperoleh oleh Meylin Putri Dewangga. Jumlah seluruh skor 1.862 .

Tabel 4.5

Daftar Frekuensi dan Persentase Skor Mentah Memahami Aspek Kebahasaan Teks Eksplanasi

\begin{tabular}{|c|c|c|c|c|}
\hline No & Nilai & (F) & Persen & Jumlah \\
\hline 1 & 48.00 & 1 & $3,8 \%$ & 48 \\
\hline 2 & 52.00 & 1 & $3,8 \%$ & 52 \\
\hline 3 & 56.00 & 1 & $3,8 \%$ & 56 \\
\hline 4 & 62.00 & 1 & $3,8 \%$ & 62 \\
\hline 5 & 68.00 & 5 & $19,2 \%$ & 340 \\
\hline 6 & 72.00 & 7 & $26,9 \%$ & 504 \\
\hline 7 & 76.00 & 2 & $7,8 \%$ & 152 \\
\hline 8 & 80.00 & 6 & $23,1 \%$ & 480 \\
\hline 9 & 84.00 & 2 & $7,8 \%$ & 168 \\
\hline & Total & $\mathbf{2 6}$ & $\mathbf{1 0 0 \%}$ & $\mathbf{1 . 8 6 2}$ \\
\hline
\end{tabular}

Berdasar pada dua tabel tersebut, nilai tertinggi adalah 84 dan nilai terendah 48. Kemudian nilai 56 dan 62 masing-masing dicapai satu atau 3,8\% peserta didik. Nilai 68 dicapai oleh lima atau $19,2 \%$ peserta didik. Nilai 76 dicapai oleh dua atau $7,8 \%$ peserta didik. Nilai 80 dicapai oleh enam atau $23,1 \%$ peserta didik. Nilai 72 diperoleh sebanyak tujuh atau $26,9 \%$ peserta didik.
Sesuai dengan penilaian di atas, dapat disimpulkan rentangan nilai yang dicapai oleh peserta didik berada pada rentang 48-84, sampel yang mendapatkan nilai dengan rentangan 76-100 hanya 10 sampel, sedangkan sampel yang memperoleh nilai dengan rentang 0-76 sebanyak 16 sampel peserta didik. Diketahui dari Tabel 4.4 jumlah nilai yang didapat peserta didik untuk memahami isi teks eksplanasi sejumlah 1.862 dengan jumlah sampel sebanyak 26 orang, dapat diperoleh nilai rerata peserta didik kelas VIII SMP Negeri 24 Banjarmasin, yaitu:

$$
\begin{array}{r}
\bar{x}=\frac{\sum x}{N} \\
\bar{x}=\frac{1.862}{26} \\
=71,61
\end{array}
$$

Nilai rerata peserta didik memahami isi teks eksplanasi adalah 71,61 .

Tabel 4.6

Kemampuan Memahami Isi teks Eksplanasi

\begin{tabular}{|l|r|r|r|}
\hline Rincian & \multicolumn{1}{|c|}{ F } & Persen & Akumulasi \\
\hline $\begin{array}{l}\text { Tidak } \\
\text { Mampu }\end{array}$ & 1 & $3,8 \%$ & 3.8 \\
\hline $\begin{array}{l}\text { Kurang } \\
\text { Mampu }\end{array}$ & 2 & $7,7 \%$ & 11.5 \\
\hline $\begin{array}{l}\text { Cukup } \\
\text { Mampu }\end{array}$ & 6 & $23,1 \%$ & 34.6 \\
\hline Mampu & 9 & $34,6 \%$ & 69,2 \\
\hline $\begin{array}{l}\text { Sangat } \\
\text { Mampu }\end{array}$ & 8 & $30,8 \%$ & 100,0 \\
\hline Jumlah & $\mathbf{2 6}$ & $\mathbf{1 0 0 . 0}$ & \\
\hline
\end{tabular}


Pada tabel tersebut dapat dilihat bahwa frekuensi terbesar terdapat sembilan (34.8\%) peserta didik yang dikatakan maтри memaham isi teks eksplanasi, sedangkan frekuensi terendah terdapat satu $(3,8 \%)$ peserta didik yang tidak mampu memahami isi teks eksplanasi. Sedangkan sisanya dua $(7,7 \%)$ peserta didik yang kurang mampu, enam $(23,1 \%)$ peserta didik yang cukup mampu, dan delapan $(30,8 \%)$ yang sangat mampu dalam memahami isi teks eksplanasi.

\section{Pembahasan}

\section{Kemampuan Memahami Aspek Kebahasaan Teks Eksplanasi}

Sesuai dengan penyajian hasil penelitian, dapat dibahas hasil dari kemampuan memahami aspek kebahasaan teks eksplanasi peserta didik kelas VIII SMP Negeri 24 Banjarmasin memperoleh nilai rerata 77,69 dengan rincian $3.8 \%$ tidak mampu, 3.8\% kurang mampu, 19.2\% сикир татри, 15.4\% татри, 57.8\% sangat mampu.

Beberapa peserta didik memperoleh nilai rendah bahkan termasuk dalam kategori tidak mampu, hal ini dikarenakan ada beberapa aspek kebahasaan yang kurang dipahami peserta didik, seperti menentukan kata benda jenis fenomena dan kata teknis. Peserta didik masih sulit membedakan antara kata benda jenis fenomena dengan kata teknis, kurang telitinya peserta didik terhadap soal yang disajikan juga menjadi penyebab lain mereka salah dalam menjawab pertanyaan.

Adapun hasil penelitian menunjukkan, kemampuan memahami aspek kebahasaan pada peserta didik kelas VIII SMP NEGERI 24 Banjarmasin masuk pada kategori maтри. Terlihat dari nilai rerata memahami aspek kebahasaan teks eksplanasi yaitu 77,69, dengan rentangan nilai 70-79.0 yang masuk kriteria mampu.

\section{Kemampuan Memahami Isi Teks Eksplanasi}

Berdasarkan dengan penyajian hasil penelitian, pembahasan hasil dari kemampuan memahami isi teks eksplanasi peserta didik kelas VIII SMP Negeri 24 Banjarmasin memperoleh nilai rerata 71,61 dengan rincian $3.8 \%$ tidak mampu, $7.7 \%$ kurang maтpu, $23.1 \%$ сикир татри, $34.6 \%$ татри, dan $30.8 \%$ sangat mampu.

Beberapa peserta didik memperoleh nilai rendah bahkan termasuk dalam kategori tidak mampu, 
ini dikarenakan peserta didik kurang teliti saat menjawab soal, selain itu peserta didik juga sulit membedakan anatara mana yang mengandung pola kausalitas dan pola kronologis. Kurangnya minat baca peserta didik juga menjadi penyebab lain, ini dapat dilihat adanya beberapa peserta didik yang mengosongkan jawaban dari lembar kerjanya ataupun menjawab dengan dua pilihan sekaligus pada lembar kerja yang disajikan.

\section{Simpulan dan Saran}

\section{Simpulan}

Sesuai dengan pemaparan pada hasil penelitian, dapat ditarik kesimpulan sebagai berikut:

1) Kemampuan peserta didik dalam memahami aspek kebahasaan teks eksplanasi adalah 77,69 dari 26 sampel peserta didik, dengan rincian tidak mampu 3,8\%, kurang mampu 3,8\%, сиkир татри 19,2\%, татри $15,4 \%$, dan sangat mampu 57,8\% Penelitian yang dilakukan memasuki kategori mатри dalam hal memahami aspek kebahasaan teks eksplanasi.

2) Kemampuan peserta didik dalam memahami isi teks ekplanasi adalah 71.61 dari 26 sampel peserta

\section{Daftar Rujukan}

Andriyani, Novita. 2016. "Peningkatan Kemampuan Memahami Aspek
Penelitian ini menunjukkan bahwa kemampuan memahami isi teks eksplanasi pesrta didiik kelas VIII SMP Negeri 24 Banjarmasin masuk pada kategori mampu(baik). Ini dapat dilihat dari nilai rerata memahami isi teks eksplanasi yaitu 71,61 dengan rentangan nilai 70-79.0 yang masuk kriteria mampu.

didik, dengan rincian tidak mampu 3,8\%, kurang mampu 7,7\%, сukup татри 23,1\%, татри 34,6\%, dan sangat mampu 30,8\%. Penelitian yang dilakukan termasuk ke dalam kategori mampu dalam memahami isi teks eksplanasi.

\section{Saran}

Kepada pendidik diharapkan berinovasi dalam kegiatan belajar mengajar supaya peserta didikk tidak bosan di kelas. Pendidik juga diharapkan memberikan bimbingan terhadap peserta didik yang gagal atau tidak mampu dalam pembelajaran yang dilaksanakan.

Kebahasaan Teks Eksplanasi Melalui Media Peta Konsep Pohon Jaringan Pada Siswa Kelas XI SMKN 5 Malang”. Publikasi daring: 
Universitas Brawijaya. (diunduh pada 4 Maret 2019).

Arikunto, Suharsimi.2010. Prosedur Penelitian Suatu Pendekatan Praktik. Jakarta: Rineka Cipta.

Fadilah, Amirah. 2018. "Kemampuan Memahami Teks Ekplanasi Siswa Kelas VII SMP NEGERI 1 Pallangga Kabupaten Gowa”. Publikasi daring: Universitas Negeri Makasar. (diunduh pada tanggal 25 Januari 2019).

Isnatun \& Umi Farida. 2013. Mahir Berbahasa Idonesia. Bogor: Yudistira.

Kemendikbud. 2013. Materi Pelatihan Implementasi Kurikulum 2013 SMA/MA dan SMK/MAK Bahasa Indonesia. Jakarta:Kementerian Pendidikan(diunduh pada 25 Februari 2019).

Kemendikbud. 2014. Buku Siswa Bahasa Indonesia SMP/MTs Kelas VIII. Jakarta: Kementrian Pendidikan dan Kebudayaan.
Kokasih, Engkos. 2013. Mandiri Mengasah Kemampuan Diri Bahasa Indonesia untuk SMP/MTs Kelas VII. Jakarta: Erlangga.

Mahsun. 2014. Teks dalam Pembelajaran Bahasa Indonesia Kurikulum 2013. Jakarta: Rajawali Pers.

Nurgiyantoro, Burhan.1998. Penilaian dalam Pengajaran Bahasa dan Sastra. Yogyakarta: BPFE IKIP Yogyakarta.

Porwadarminta. 2003. Kamus Besar Bahasa Indonesia. Jakarta: Balai Pustaka.

Prasetyo, Bambang dan Lina Miftahul Jannah. 2012. Metode Penelitian Kuantitatif. Jakarta: Rajawali Pers.

Priyatni, Endah Tri. 2017. Desain Pembelajaran Bahasa Indonesia. Jakarta: Bumi Aksara.

Purwanto, Ngalim. 2000. Prinsi-Prinsip dan Teknik Evaluasi Pengajaran. Bandung: Pt. Remaja Rosdakarya.

Sudijono, Anas. 2009. Pengantar Evaluasi Pendidikan. Jakarta: Rajawali Pers. 